\title{
IS THERE A RELATIONSHIP BETWEEN SCHOOL FACTORS AND STUDENTS' CITIZENSHIP EDUCATION? THE CASES OF LATVIA AND FINLAND BASED ON IEA ICCS 2016 DATA
}

\author{
Ireta Čekse, Reinis Alksnis \\ University of Latvia, Latvia
}

\begin{abstract}
In this research, the aim was to determine teacher- and school-level factors that are associated with students' civic knowledge, future engagement in society as a citizen, opinions about future global issues and sense of belonging to their country. For that purpose, the research took IEA International Civic and Citizenship Education Study (ICCS 2016) questionnaire data from Latvian and Finnish students (Latvia $n=3224$, Finland $n=3173$ ), teachers (Latvia $n=1933$, Finland $n=2097$ ) and schools (Latvia $n=137$, Finland $n=174)$. The study used a subset of the teacher dataset that corresponds only to those teachers who teach civic and citizenship education lessons in school (Latvia $n=131$, Finland $n=165$ ). The research shows that there are some significant relationships with teacher- and school-level factors and four student factors: civic knowledge, future engagement, sense of belonging to their country and global problems (sustainability, violence and economy). The research supported by research application no. 1.1.1.2/VIAA/1/16/020.
\end{abstract}

Keywords: citizenship education, ICCS 2016, Finland, Latvia, multivariable regression analysis, school factors.

\section{Introduction}

Citizenship education has an essential role in the education process and "refers to how education can support students' development of identity" (Veugelers \& Groot, 2019, 15). Over time, citizenship education goals have changed according to the concept of citizenship and local and global issues in politics and economics (WTO, 2010). Also, the definition of what a citizens must be according to the activities they do has become important. Horst and colleagues (2020) talk about the "good citizen" as an active citizen, where an individual assess themself and his activities and acts according to values that are considered desirable by the welfare state. In 
the "global citizenship" concept, individuals see themselves as members of a wider community in which they, as "global citizens" participate in a common job market, and live in a community without statehood, institutions and passports (Sterri, 2015). "Digital citizenship" is the ability to participate in society online (Mossberger et al., 2008). Nowadays, social platforms offer vehicles of civic participation and allow people to become "digital citizens". That raises questions about the competencies of digital citizenship, as well as about the meaning of digital citizenship, digital rights and digital literacy, and preparing individuals adequately (Sefton-Green \& Pangrazio, 2021).

School has an important role in each person's life. And teachers are key agents in formal education area (Sampermans et al., 2021). Formal and life experiences from school are highlighted during one's whole life. That is why the the schooling period is so important for one's personality to develop a sense of belonging, engagement, formal achievements, critical thinking and a view of local and global problems. Impressions on individual achievements and attitudes come from different factors like school, family and society (Schulz et al., 2017). Several school factors might be teachers' personality, the principal's leadership style and skills, the school environment, the location and size of the school, and other students in the school.

A relevant factor that describes citizens' participation in society is engagement. Engagement is a concept where citizens need to feel concerned about issues with issues and information in their communities in order to participate effectively (Schulz et al., 2008). But to be successful participants in society, they need to have a high level of civic knowledge and citizenship education. Civic knowledge is like a tool that helps citizens understand their interests as individuals and as members of groups. The more knowledge students have, the better they can understand the impact of public policies on their interests and the more effectively they can promote their interests in the political process (Galston, 2007).

Accordingly, it is important to acknowledge school-level factors that make an impression on students' citizenship knowledge and attitudes towards local and global issues. That is why the aim of this article is to determine school-level factors that are associated with students' civic knowledge, future engagement in society as a citizen, their opinion about future global issues, and their sense of belonging to their country. Research question: what is there a relationship between school factors and students' citizenship education?

\section{Method}

In order to address research question, we have utilized data from the IEA's International Civic and Citizenship Education Study (ICCS) 2016 (data available at https://doi.org/10.3886/ICPSR37147.v1). The IEA's ICCS 
provides a rich source of data that reveals considerable variation among and within countries about the provision ofcivic and citizenship education (CCE), as well as the civic knowledge of students, sense of democracy, etc. The 2016 study is the fourth ICCS study that aimed to find out the ways in which young people are prepared to undertake their roles as citizens (Schulz et al., 2016).

All of the response variables in this study were obtained by utilizing data from Latvia's and Finland's student questionnaires (Latvia $n=3224$, Finland $n=3173$ ). Corresponding datasets of teachers' and principals' responses were used as explanatory variables. Subsets of only those teachers who teach a civic and citizenship education-related subject in Grade 8 were chosen from the teachers' questionnaires (Latvia $n=131$, Finland $n=165)$. Data from these questionnaires contain variables describing teachers' professional activities, their students' and parents' activities in school and the local community, teachers' perceptions of students' behaviour, bullying in school and the class climate. The school datasets consist of principals' responses (Latvia $n=137$; Finland $n=174$ ). These answers describe basic information about the school and resources of the local community, principals perception of teachers and students activities, and teachers and students sense of belonging to the school.

In the first stage of this study, a combined dataset was created with schools as the observed variables. Corresponding teacher variables were averaged within schools. Then the obtained averaged teachers' dataset was merged with the school dataset by matching the school indicators (IDSCHOOL). To investigate the association between school factors and students' civic knowledge, plausible values from students' tests were utilized. To make any inference, all five plausible values (measurements of civic knowledge) needed to be used. Hence we imputed five datasets for each plausible value, then computed weighted means within all schools and finally combined the results, thus obtaining a school's average civic knowledge score. These values were added to the merged dataset. For the exploration of other facets of civic attitudes and engagement, items from the International Student Questionnaire were used. Study to investigate the associations of school factors with such civic characteristics as students' future engagement, their concerns about global issues and their sense of belonging to their country.

The variable "Future engagement" (18 items) was meant to describe students' possible future engagement in society. Due to the somewhat large amount of items, confirmatory factor analysis was used to test its unidimensionality. Unacceptably low model fit measures were obtained (CFI and TLI below 0.50, RMSEA and SRMR above 0.12 for both countries), so it was decided to investigate associations between school factors 
and potential future engagement by constructing four separate models with scales already provided in a student data file built from these items. Consequently, four aspects of engagement were investigated: students' expected participation in illegal protest activities (S_ILLACT), students' expected participation in legal activities (S_LEGACT), students' expected electoral participation (S_ELECPART), and students' expected active political participation (S_POLPART). For the same reasons, the variable named "Global issues" (12 items), which was meant to describe students' attitudes towards global problems, was also divided into three subscales. Here, the question "To what extent do you think the following issues are a threat to the world's future" was asked. Several potential threats were given, and students were asked to choose the extent to which they are concerned about them. Answers about pollution, energy shortages, water shortages, food shortages, climate change and overpopulation were used to construct the sustainability scale. Its internal consistency was measured with Cronbach's alpha, which was 0.73 for Latvia and 0.80 for Finland. Answers about crime, violent conflict and terrorism as global threats were used to construct the violence scale, which had Cronbach's alpha values of 0.67 (Latvia) and 0.71 (Finland). Answers about the global financial crisis, poverty and unemployment as global threats were used to create the economy scale, which had Cronbach's alpha values of 0.66 (Latvia) and 0.70 (Finland). The remaining answer about infectious diseases was omitted since it did not fit well with any of the three scales. Confirmatory factor analysis was used to test the proposed latent variable structure. An acceptable model was obtained with the following fit statistics: CFI $=0.938$ (Latvia), CFI $=0.939$ (Finland), TLI $=0.913$ (Latvia), TLI $=0.917$ (Finland), RMSEA $=0.062$ (Latvia), RMSEA $=0.073$ (Finland), SRMR $=0.035$ (Latvia) and SRMR $=0.036$ (Finland). The scores of these latent variables were obtained by using a generalized partial credit model from item response theory and estimated with weighted maximum likelihood. Finally, the variable called "Sense of belonging to the country" was created from 3 items. Here, the question "How much do you agree or disagree with the following statements about the test country" was asked. The following items were used to create the values scale: the flag of the country is important to me; I have great respect for the test country; we should be proud of what we have achieved in the test country. The Cronbach's alpha values were 0.87 for Latvia and 0.86 for Finland. This scale was used to investigate school factors that may be related to students' respect for and pride in the country he/she lives in. Finally, each of the obtained scales was averaged at the school level and added to the previously merged dataset.

To investigate which school factors may be related to students' civic characteristics, we used a survey-weighted multivariable regression analysis 
where school weights were attached to observations. Since all of the school and teacher factors that were used in this analysis could potentially have some influence on students' level of knowledge and different attitudes, at least from a theoretical point of view, a model was first constructed with all school and teacher variables as predictors for each of the explanatory variables. Then, sequentially, the least significant predictors were dropped, thus finally providing a model with only statistically significant variables remaining. The number of predictors in the final model varied between one and seven. For all the models reported, the adjusted R-square varied between $2.8 \%$ and $29 \%$. The variance inflation factor was below 3.4 for all the predictors that were considered.

All of the analyses were conducted with statistical software R. To take the complex survey design into account, appropriate functions from the survey package were used. To perform multiple imputations of plausible values, the mitools package was used. To test unidimensionality and the proposed latent variable structure, the lavaan.survey package was used. To create scales in the item response theory framework, the mirt package was used.

\section{Results}

In this section, we describe the obtained results. For each model with more than three significant predictors, a table is provided with descriptive names for the significant predictors, regression coefficients (standardized for continuous predictors), standard error and p-values.

\section{Civic knowledge}

First, we constructed a model to explore which school factors could be related to the level of students' civic knowledge. For Latvian students, it appears that background variables such as school size and teacher's age (see Table 1) are the factors that may be related to their scores on a civic knowledge test. According to this model, their level of knowledge is positively related to school size. Based on the number of students, schools were divided into four categories with 50 (Finland $n=36$ ) schools in the first category with less than 300 students, 44 (Finland $n=99$ ) schools in the second with 301 to 600 students, 28 (Finland $n=28$ ) schools in the third with 601 to 900 students, and 9 (Finland $n=2$ ) schools in the fourth with more than 900 students. In Table 1, the first category is used as a reference category, meaning that students from schools in the second category scored on average 22.9 points more than those in the first category. Moreover, students from schools in the third category scored on average 42 points more than those in the first category, and students from schools in the 
fourth category scored on average 46 points higher than those in the first category. Apparently, a positive relation exists, however causality cannot be deduced. It would be reasonable to assume some third factors being positively associated with school size and level of civic knowledge.

Table 1. Regression output of the model for Latvian students with civic knowledge as the response variable

\begin{tabular}{|l|c|c|c|}
\hline & Coefficient & Standard Error & $\boldsymbol{P}$-value \\
\hline C_SCSIZE_CAT2 & 23.00 & 11.21 & $0.04^{*}$ \\
\hline C_SCSIZE_CAT3 & 42.73 & 10.75 & $<0.00^{* *}$ \\
\hline C_SCSIZE_CAT4 & 46.33 & 14.99 & $<0.00^{* *}$ \\
\hline T_AGE & -14.11 & 3.73 & $<0.00^{* *}$ \\
\hline
\end{tabular}

In contrast, teachers' age appears to be negatively related to the civic knowledge level of Latvian students. With an additional year of average teacher age, students score on average 1.8 points lower. The adjusted R-square of the final model was $15 \%$. A similar model was constructed to investigate what kind of factors may be related to Finnish students' civic knowledge level (see Table 2). School size and teachers' age were not significant predictors in this model, however there appear to be positive associations with more nuanced predictors such as availability of resources (C_AVRESCOM), environment-friendly practices at school (C_ENPRAC), teachers' perception of students' behaviour (T_STUDB), and social problems at school (T_PROBSC). A negative association was observed between civic knowledge and frequency of activities against bullying at school (C_BULACT), teachers' perception of the classroom climate (T_PCCLIM), and their perception of other teachers' participation at school (T_TCHPRT). The adjusted R-square for this model was $22 \%$.

Table 2. Regression output of the model for Finnish students with civic knowledge as the response variable

\begin{tabular}{|l|c|c|c|}
\hline & Coefficient & Standard Error & $P$-value \\
\hline C_AVRESCOM & 5.53 & 2.41 & $0.02^{*}$ \\
\hline C_BULACT & -5.10 & 2.59 & $0.05^{*}$ \\
\hline C_ENPRAC & 9.41 & 2.40 & $<0.01^{* *}$ \\
\hline T_PCCLIM & -8.36 & 4.27 & $0.05^{*}$ \\
\hline T_PROBSC & 5.65 & 3.21 & 0.08 \\
\hline T_STUDB & 7.87 & 4.11 & 0.06 \\
\hline T_TCHPRT & -3.84 & 2.27 & 0.10 \\
\hline
\end{tabular}


Demographic factors such as age and gender can be logically explained in the case of Latvia. First, the majority of Latvian teachers are women who are more than 45 years old (TALIS, 2014). According to this, we can assume that their life experience of living in the Soviet Union and the first decade after the restoration of national independence had an influence on teachers' attitudes to citizenship issues and teaching methods. In addition, the Latvian and Finnish results both highlighted the importance of background factors that should be kept in mind for the education environment and higher achievement in citizenship education. Alivernini and Manganelli (2011) mentioned an open classroom climate as one of the preconditions for a higher level of knowledge. In summary, background issues are critical for civic knowledge and must be viewed as specific conditions during the learning process.

\section{Sense of Belonging to the Country}

In the final model, in which the sense of belonging to the country scale was a response variable, for Latvian students (see Table 3), there was a positive relationship with the principals perception of crime in the community and environment-friendly practices at school as well as teachers' perceptions of student activities in the community. A negative association was observed between the principal's perception of social tension due to ethnic differences in the community, the school's urbanization level, the principal's perception of the engagement of the school community, and the teacher's teaching load at school. Also, it appears that students from schools with 601-900 students score significantly lower than students from smaller schools. The adjusted R-square for this model was $29 \%$.

Table 3. Regression output of the model for Latvian students with sense of belonging values as the response variable

\begin{tabular}{|l|c|c|c|}
\hline & Coefficient & Standard Error & $\boldsymbol{P}$-value \\
\hline C_SCSIZE_CAT2 & -0.79 & 0.67 & 0.25 \\
\hline C_SCSIZE_CAT3 & -2.63 & 0.78 & $<0.00^{* *}$ \\
\hline C_SCSIZE_CAT4 & 0.15 & 0.70 & 0.83 \\
\hline C_COMCRI & 0.98 & 0.39 & $0.01^{* *}$ \\
\hline C_COMETN & -1.13 & 0.51 & $0.03^{*}$ \\
\hline C_URBAN & -2.23 & 0.68 & $<0.00^{* *}$ \\
\hline C_ENGAGE & -0.56 & 0.22 & $0.01^{* *}$ \\
\hline C_ENPRAC & 0.72 & 0.35 & $0.04^{*}$ \\
\hline T_TIME & -0.54 & 0.27 & $0.05^{*}$ \\
\hline T_STDCOM & 0.70 & 0.32 & $0.03^{*}$ \\
\hline
\end{tabular}


In a similar model for Finnish students, only one significant predictor (T_GENDER) remained in the final model (Coefficient 1.27, Standard Error $0.72, P$-value 0.08 ). This predictor indicated average higher scores when the teacher is a female. For this model, the R-square was $18 \%$. However, there could be other predictors that have an influence on sense of belonging to the country values. There is no gender equality, for example, as $80 \%$ of all respondents in Latvia are women, and in Finland - 32\%.

\section{Future engagement}

Of the four aspects of possible future engagement, the association between school factors and participation in illegal protest activities was investigated first (see Table 4).

Table 4. Regression output of the model for Latvian students with expected engagement in illegal protest as the response variable

\begin{tabular}{|l|c|c|c|}
\hline & Coefficient & Standard Error & $\boldsymbol{P}$-value \\
\hline C_COMETN & 0.81 & 0.39 & $0.04^{*}$ \\
\hline T_AGE & 0.77 & 0.35 & $0.03^{*}$ \\
\hline T_STUDB & -1.06 & 0.50 & $0.04^{*}$ \\
\hline
\end{tabular}

In the case of Latvian students, the final model shows a positive relationship between participation in illegal activities and the principal's perceptions of social tension due to ethnic differences in the community. We consider that the reason for this could be pressure between Latvian- and Russian-speaking groups due to the struggle for minority schools' rights and Russian being the dominant learning language in schools. To extenuate this aspect might be possible with activities that explain the significance of legal protest activities in society and engaging with ethnic groups' rights and the rules of living in Latvia. Also, teachers' age appears to be positively correlated with the tendency to participate in illegal protests. On the other hand, teachers' perception of students' behaviour at school seems to have a negative relationship with participation in illegal protests. The adjusted R-square of this model was $14 \%$. This kind of result can be explained by the relationship with the level of students' achievement. First, there could be a relationship between students with a low level of knowledge and participation in illegal protest activities. Another group include students with a high level of achievement who have been radicalized (Biseth et al., 2021). In the case of Latvia, the first of these could be plausible.

However, a similar model for Finnish students (see Table 5) shows that participation in illegal protests is negatively associated with teachers' 
perceptions of social problems at school and teachers' preparedness for teaching CCE topics. This can be explained by, on the one hand, the social tension that reduces the willingness to participate in civic activities and, on the other hand, the "Greta Thunberg generation" which can be described as a part of the youth who have been radicalized (Biseth et al., 2021). The results also show that students from schools with 601 to 900 students tend to participate less in such activities. Since only two schools are in the fourth category with more than 900 students, this shows that students who participate in illegal protests generally come from smaller schools (less than 600 students). On the other hand, there seems to be a positive association with schools' composition by student background, principals' responses on activities against bullying at school, teachers' responses on civic-related activities in class, and teachers' perceptions of student participation at school. Similarly to Latvian students, teachers' age also appears to have a positive relationship with participation in illegal protests. The adjusted R-square for this model was $22 \%$.

Table 5. Regression output of the model for Finnish students' participation in illegal protests

\begin{tabular}{|l|c|c|c|}
\hline & Coefficient & Standard Error & $\boldsymbol{P}$-value \\
\hline C_COMP & 0.56 & 0.26 & $0.04^{*}$ \\
\hline C_SCSIZE_CAT3 & -1.62 & 0.73 & $0.03^{*}$ \\
\hline C_BULACT & 0.45 & 0.24 & 0.07 \\
\hline T_AGE & 0.63 & 0.23 & $0.01^{* *}$ \\
\hline T_CIVCLAS & 0.54 & 0.28 & $0.05^{*}$ \\
\hline T_PROBSC & -0.65 & 0.24 & $0.01^{* *}$ \\
\hline T_PRPCCE & -0.56 & 0.26 & $0.03^{*}$ \\
\hline T_TCHPRT & 0.61 & 0.26 & $0.02^{*}$ \\
\hline
\end{tabular}

\section{Future engagement in legal protest activities}

In the final model for students' participation in legal protest activities, the following results were obtained (see Table 6). For Latvian students, the final model shows a positive relationship with principals' responses on environment-friendly practices at school and their perceptions of teachers' sense of belonging to the school. The results highlight the importance of teachers' wellbeing (Spil \& Koomen, 2011) and motivating students to deal with conflict in a nonviolent way. There seems to be a negative association between participation in legal protest activities and principals' perceptions of teachers' participation in school governance. The corresponding adjusted R-square was $10 \%$. 
Table 6. Regression output for Latvian students with participation in legal protest activities as the response variable

\begin{tabular}{|l|c|c|c|}
\hline & Coefficient & $\begin{array}{c}\text { Standard } \\
\text { Error }\end{array}$ & $P$-value \\
\hline C_ENPRAC & 0.75 & 0.28 & $0.01^{* *}$ \\
\hline C_TCPART & -1.06 & 0.33 & $<0.01^{* *}$ \\
\hline C_TCSBELS & 0.73 & 0.37 & $0.05^{*}$ \\
\hline
\end{tabular}

In a similar model for Finish students (see Table 7), participation in legal protest activities seems to be positively associated with principals' perceptions of the engagement of the school community and teachers' perceptions of teacher participation at school, while there is a negative association with principals' perceptions of poverty in the community. The adjusted R-square was $12 \%$.

Table 7. Regression output for Finnish students with participation in legal protest activities as the response variable

\begin{tabular}{|l|c|c|c|}
\hline & Coefficient & $\begin{array}{c}\text { Standard } \\
\text { Error }\end{array}$ & $P$-value \\
\hline C_COMPOV & -0.47 & 0.20 & $0.02^{*}$ \\
\hline C_ENGAGE & 0.55 & 0.18 & $<0.01^{* *}$ \\
\hline T_TCHPRT & 0.33 & 0.16 & $0.04^{*}$ \\
\hline
\end{tabular}

Biseth et al. (2021) found that the experiences of Northern European countries (Denmark, Sweden, Norway, Finland) highlighted the relationship between students' participation in legal citizenship activities and a higher level of citizenship knowledge. Moreover, that increases the need for a holistic approach to citizenship education. However, in general, we can assume that citizenship practices at the school level and activities in the school provide positive support for better participation in decision-making processes and support active participation in society in the future.

\section{Future engagement as expected electoral participation}

This model (see Table 8) shows that Latvian students' expected electoral participation may be positively associated with principals' perceptions of teachers' sense of belonging to the school but negatively associated with teachers' preparedness for teaching CCE topics as well as the school's urbanization status and the teacher's age. The adjusted R-square was $13 \%$. 
Table 8. Regression output for Latvian students with expected electoral participation as the response variable

\begin{tabular}{|l|c|c|c|}
\hline & Coefficient & Standard Error & $\boldsymbol{P}$-value \\
\hline C_URBAN1 & -1.21 & 0.65 & 0.07 \\
\hline C_TCSBELS & 0.86 & 0.35 & $0.02^{*}$ \\
\hline T_AGE & -0.81 & 0.34 & $0.02^{*}$ \\
\hline T_PRPCCE & -0.87 & 0.37 & $0.02^{*}$ \\
\hline
\end{tabular}

A similar model for Finnish students shows only one significant variable: students' expected electoral participation seems to be negatively associated with schools' composition by student background (Coefficient -1.6, Standard Error 0.50, $P$-value 0.01). The adjusted R-square for this model was $18 \%$.

\section{Future engagement as expected political participation}

In the model with Latvian students' expected political participation as the response variable (see Table 9), a positive association can be observed with principals' perceptions of teachers' sense of belonging to the school and teachers' teaching load at school. There appears to be a negative association with principals' perceptions of teachers' participation in school governance. Also, students from larger schools with more than 600 students seem to be more inclined to political participation. The adjusted R-square was $16 \%$.

The results also support the idea of the teacher as an educator, not an administrative person in the school. At the same time, useful questions related to the results could be asked, for example, what does a teacher having a sense of belonging to the school mean - is it about care and responsibility for the values of the school, is it about wellbeing, or is it something else? The results of Latvia on this issue are still open to deeper observations in future research.

Table 9. Regression output for Latvian students with expected political participation as the response variable

\begin{tabular}{|l|c|c|c|}
\hline & Coefficient & Standard Error & P-value \\
\hline C_SCSIZE_CAT3 & -2.87 & 0.71 & $<0.01^{* *}$ \\
\hline C_SCSIZE_CAT4 & -2.17 & 1.05 & $0.04^{*}$ \\
\hline C_TCPART & -1.09 & 0.41 & $0.01^{* *}$ \\
\hline C_TCSBELS & 0.86 & 0.36 & $0.02^{*}$ \\
\hline T_TIME & 0.69 & 0.26 & $0.01^{* *}$ \\
\hline
\end{tabular}


In a similar model for the expected political participation of Finnish students (see Table 10), a positive association can be observed with principals' perceptions of students' opportunities to participate in community activities, teachers' preparedness for teaching CCE topics, and teachers' perceptions of student behaviour at school. The results support the fact that Finland's national curricula for comprehensive education have been emphasizing democratic values since the 1970s and have supported teachers in citizenship education. This is indicated by the democratic culture tradition in the school environment and the target to support civic participation and increase active citizenship (Rautiainen et al., 2020). For example, the Civic Education Study (CivEd) and ICCS indicate that between 1999 and 2016, students' democratic activities (e. g. decision-making, voting in class or school elections, etc.) in schools rose (Schulz et al., 2017; Amadeo et al., 2002). However, a negative association can be observed with principals' perceptions of poverty in the community and teachers' perceptions of the classroom climate. The adjusted R-square was $16 \%$.

Table 10. Regression output for Finnish students with expected political participation as the response variable

\begin{tabular}{|l|c|c|c|}
\hline & Coefficient & Standard Error & P-value \\
\hline C_COMPOV & -0.67 & 0.16 & $<0.01^{* *}$ \\
\hline C_STDCOM & 0.33 & 0.18 & 0.07 \\
\hline T_PCCLIM & -0.70 & 0.31 & $0.03^{*}$ \\
\hline T_PRPCCE & 0.37 & 0.14 & $0.01^{* *}$ \\
\hline T_STUDB & 0.64 & 0.33 & $0.05^{*}$ \\
\hline
\end{tabular}

\section{Global issues}

There are three sub-categories under the heading Global issues.

First, economic factors. In the model for Latvian students, there was a positive association between students' perception of economic threats and principals' perceptions of poverty in the community and teachers' sense of belonging to the school (see Table 11). A negative relationship was observed with principals' perceptions of teachers' participation in school governance and teachers' gender, and school size also appeared to be negatively associated with students' perception of economic threats. The corresponding adjusted R-square was $27 \%$. In a similar model for Finnish students, two predictors remained as significant in the final model: a positive association was observed with principals' perceptions of student 
opportunities to participate in community activities (Coefficient 0.65 , Standard Error 0.24, $P$-value 0.01), while there was a negative association with principals' responses on activities against bullying at school (Coefficient -0.56 , Standard Error 0.25, $P$-value 0.03). The adjusted R-square was $4.1 \%$.

Table 11. Regression output for Latvian students with economic threats as the response variable

\begin{tabular}{|l|c|c|c|}
\hline & Coefficient & Standard Error & P-value \\
\hline C_SCSIZE_CAT2 & -1.86 & 0.70 & $0.01^{* *}$ \\
\hline C_SCSIZE_CAT3 & -2.30 & 0.69 & $<0.01^{* *}$ \\
\hline C_SCSIZE_CAT4 & -3.54 & 1.07 & $<0.01^{* *}$ \\
\hline C_COMPOV & 0.78 & 0.35 & $0.03^{*}$ \\
\hline C_TCPART & -1.62 & 0.53 & $<0.01^{* *}$ \\
\hline C_TCSBELS & 1.00 & 0.25 & $<0.01^{* *}$ \\
\hline T_GENDER & -0.32 & 0.17 & 0.07 \\
\hline
\end{tabular}

Second, violence. In the model for Latvian students (see Table 12), there was a positive association with teachers' perception of the classroom climate and students' activities in the community and a negative association with principals' perceptions of teachers' participation in school governance and teachers' preparedness for teaching CCE topics. The adjusted R-square was $22.4 \%$. In the corresponding model for Finnish students (see Table 13), there was a positive association with principals' perceptions of crime in the community, principals' responses on environment-friendly practices at school, principals' perceptions of students' sense of belonging to the school and teachers' teaching load at school. Negative associations were observed with principals' responses on activities against bullying at school, teachers' preparedness for teaching CCE topics and teachers' gender, meaning higher scores on average were seen when the teacher is a male. The adjusted R-square was $13.5 \%$.

Table 12. Regression output for Latvian students with violent conflicts as the response variable

\begin{tabular}{|l|c|c|c|}
\hline & Coefficient & Standard Error & P-value \\
\hline C_TCPART & -0.59 & 0.34 & 0.09 \\
\hline T_PCCLIM & 0.98 & 0.43 & $0.03^{*}$ \\
\hline T_PRPCCE & -0.97 & 0.35 & $0.01^{* *}$ \\
\hline T_STDCOM & 0.92 & 0.44 & $0.04^{*}$ \\
\hline
\end{tabular}


Table 13. Regression output for Finnish students with violent conflicts as the response variable

\begin{tabular}{|l|c|c|c|}
\hline & Coefficient & Standard Error & P-value \\
\hline C_BULACT & -0.54 & 0.20 & $0.01^{* *}$ \\
\hline C_COMCRI & 0.69 & 0.22 & $<0.01^{* *}$ \\
\hline C_ENPRAC & 0.41 & 0.19 & $0.03^{*}$ \\
\hline C_STSBELS & 0.50 & 0.20 & $0.01^{* *}$ \\
\hline T_GENDER & -0.44 & 0.23 & 0.06 \\
\hline T_TIME & 0.67 & 0.25 & $0.01^{* *}$ \\
\hline T_PRPCCE & -0.57 & 0.16 & $<0.01^{* *}$ \\
\hline
\end{tabular}

Finally, a model was constructed with the sustainability scale as a response variable. For Latvian students, a positive association was observed with principals' responses on the availability of resources in the local community (Coefficient 0.55, Standard Error 0.28, P-value 0.06), while a negative association was observed with teachers' age (Coefficient -1.03, Standard Error 0.31, P-value $<0.01$ ). The adjusted R-square was $8.7 \%$. In the case of Finnish students (see Table 14), there were positive associations with the school's urbanization level and principals' responses on environment-friendly practices at school. There were negative associations with principals' responses on activities against bullying at school and teachers' preparedness for teaching CCE topics. The corresponding adjusted R-square was $5.2 \%$.

Table 14. Regression output for Finnish students with sustainability as the response variable

\begin{tabular}{|l|c|c|c|}
\hline & Coefficient & Standard Error & $P$-value \\
\hline C_URBAN & 0.93 & 0.54 & 0.09 \\
\hline C_BULACT & -0.55 & 0.27 & $0.04^{*}$ \\
\hline C_ENPRAC & 0.46 & 0.21 & $0.03^{*}$ \\
\hline T_PRPCCE & -0.47 & 0.22 & $0.04^{*}$ \\
\hline
\end{tabular}

\section{Discussion}

Our aim was to determine school-level factors that are associated with students' civic knowledge, future engagement in society as a citizen, opinions about future global issues, and their sense of belonging to their country. The empirical strategy for this was to take school-level predictors and 
compare these with response variables from student data. We looked specifically at the cases of Finland and Latvia with the task to find out the most characteristic school factors that have an influence on students' civic knowledge and their attitudes and opinions about issues related to citizenship. The aim of this was to recognize differences between both countries, to find out more about Finland's education success story, and to determine factors that can be important improvements for Latvia's citizenship education.

According to the results of the research, we observed that schools and teachers have an essential role in citizenship education. Teachers' background factors have a notable influence on students' level of citizenship education in Latvia. The results showed that older teachers in Latvia have a negative relationship with the level of citizenship education and attitudes to important global citizenship issues. There are negative relationships between teachers' age and students' civic knowledge, opinions about sustainability and global issues. In the case of Finland, teachers' age did not play a statistically significant role at the level of students' civic knowledge and citizenship attitudes. Teachers' more common influence on students' knowledge and citizenship attitudes. That results for Finland can be expalned as the conciseness of education reforms since the 1970s and Finland teachers' education content at a national level (Rautiainen et al., 2020). However, Latvia has had shorter practice with democracy, and there is still post-Soviet thinking that influences national ideology. In summary, older teachers in Latvia still have post-Soviet thinking in the educational space (Rubene, 2009).

However, the context of each country and its education policy also have important roles in citizenship education. The results show that, in Finland, schools' and teachers' support for wellbeing (Seligman, 2011) has an impact on higher levels of civic knowledge, the sense of belonging to one's country, and attitudes towards global issues. Another survey (OECD, 2018) also highlighted that Finland's unique teacher preparation approach and education policy (OECD, 2020) is a predictor of its strong and quality teacher workforce (Hammerness et al., 2017). Hovever, resech results show that In Latvia case, the concept of wellbeing does not have a substantial impact; instead, a crucial role is played by the geographical location of the school and the size of the school. Based on IEA PIRLS results, Johansone (2009) also mentioned urbanization and the size of schools as factors that have an impact on students' wellbeing and achievement. Our observation highlighted that students at small-sized schools from low socioeconomic backgrounds do not pay attention to global issues. This could be a disadvantage in the future for a democratic society as it might develop an unsustainable understanding of citizenship and be an insecure place to live. 
In conclusion, there are different relationships between school factors and student citizenship education in Latvia and Finland. The explanation for this could be the historical and cultural contexts of both countries. Finland has purposefully built its education system since the 1970s with the aim of getting a stronger economic system (Rautiainen et al., 2020). Latvia, however, only regained independence from the Soviet Union at the beginning of the 1990s and had to rebuild its democratic society and institutions from the beginning. This has had an influence on its education system, education aims and citizenship education. Nowadays, to get a higher level of citizenship education for Latvia's students, more focus should be put on wellbeing in society and on expanding the importance of global issues and the relevance of a sense of belonging to one's country.

\section{References}

Alivernini, F., \& Manganelli, S. (2011). Is There a Relationship between Openness in Classroom Discussion and Students' Knowledge in Civic and Citizenship Education? Procedia, Social and Behavioral Sciences, 15, 3441-3445.

Amadeo, J.-A., Torney-Purta, J., Lehmann, R., Husfeldt, V., \& Nikolova, R. (2002). Civic Knowledge and Engagement: An IEA study of upper secondary students in sixteen countries. IEA.

Biseth, H., Hoskins, B., \& Huang, L. (2021). Using IEA International Civic and Citizenship Education Study (ICCS) Data: Northern Lights on ICCS. In H. Biseth, B. Hoskins, \& L. Huang (Eds.), Northern Lights on Civic and Citizenship Education A Cross-national Comparison of Nordic Data from ICCS. IEA Research for Education.

Galston, W. A. (2007). Civic Knowledge, Civic Education, and Civic Engagement: A Summary of Recent Research. International Journal of Public Administration, 30(6-7), 623-642. doi:10.1080/01900690701215888

Hammerness, K., Ahtiainen, R., \& Sahlberg, P. (2017). Empowered educators in Finland: How high-performing systems shape teaching quality. Jossey-Bass.

Horst, C., Erdal, M. B., \& Jdid, N. (2020). The "Good Citizen": Asserting and Contesting Norms of Participation and Belonging in Oslo. Ethnic and Racial Studies, 46(16), 76-95. doi:10.1080/01419870.2019.1671599

Johansone, I. (2009). Managing primary education in Latvia to assure quality and achievement equity [Unpublished doctoral dissertation]. University of Latvia.

Mossberger, K., McNeal, R. S., \& Caroline, J. T. (2008). Digital citizenship: The internet, society, and participation. MIT Press.

OECD. (2018). Education at a glance 2018: OECD indicators. OECD Publishing.

OECD. (2020). Education policy outlook in Finland. OECD Publishing.

Rautiainen, M., Männistö, P., \& Fornaciari, A. (2020). Democratic citizenship and teacher education in Finland. In A. Raiker, M. Rautiainen, \& B. Saqipi (Eds.), Teacher education and the development of democratic citizenship in Europe (pp. 62-73). Routledge.

Rubene, Z. (2009). Topicality of Critical Thinking in the Post-Soviet Educational Space. European Education, 41(4), 24-40. https://doi.org/10.2753/EUE1056-4934410402 
Sampermans, D., Reichert, F., \& Claes, E. (2021). Teachers' concepts of good citizenship and associations with their teaching styles. Cambridge Journal of Education. https:// doi.org/10.1080/0305764X.2020.1861219

Schulz, W., Ainley, J. F., Fraillon, J., Losito, B., Agrusti, G., \& Tim, F. (2017). Becoming citizens in a changing world: IEA international civic and citizenship education study 2016 international report. Springer.

Schulz, W., Ainley, J. F., Losito, B., \& Agrusti, G. (2016). Assessment framework. Springer.

Schulz, W., Frallion, J., Ainley, J., Losito, B., \& Kerr, D. (2008). Internacional civic and citizenship education study. Assessment framework. IEA.

Sefton-Green, J., \& Pangrazio, L. (2021). Digital Rights, Digital Citizenship and Digital Literacy: What's the Difference? Journal of New Approaches in Educational Research, 10(1), 15-27.

Seligman, M. E. (2011). Flourish: A visionary new understanding of happiness and wellbeing. Atria Books.

Spil, J., \& Koomen, H. T. (2011). Teacher Wellbeing: The Importance of TeacherStudent Relationships. Educational Psychology Review, 23(4), 457-477.

Sterri, A. B. (2015). Global citizen - challenges and responsibility in an interconnected world (New Research - New Voices 3). Birkhäuser Boston.

TALIS. (2014.) TALIS 2013 results: An international perspective on teaching and learning. OECD Publishing. https://dx.doi.org/10.1787/9789264196261-en

Veugelers, W., \& Groot, I. (2019). Theory and Practice of Citizenship Education. In W. Veugelers (Ed.), Education for democratic intercultural citizenship (pp. 14-41). Brill. doi:10.1163/j.ctvrxk389.6

WTO. (2010). Global problems, global solutions: Towards better global governance. WTO Publications. 